\title{
Erratum to: Strong ion reserve: a viewpoint on acid base equilibria and buffering
}

\author{
Michalis Agrafiotis
}

Published online: 30 January 2011

(C) Springer-Verlag 2011

\section{Erratum to: Eur J Appl Physiol}

\section{DOI 10.1007/s00421-010-1803-1}

In the original publication of this article, last two sentences of the abstract section had errors. The correct text should read as "These recruitable strong ions represent the solution's 'strong ion reserve'. The physiologic role of these protein-bound strong ions in the buffering of acid base disorders is discussed".

The online version of the original article can be found under doi:10.1007/s00421-010-1803-1.

M. Agrafiotis $(\square)$

Second Department of Intensive Care Medicine,

"Georgios Papanikolaou" General Hospital of Thessaloniki, 57010 Exochi, Greece

e-mail: m.agrafiotis@gmail.com 